\title{
Effects of Temperature on Denitrifying Growth and Nitrate Reduction End Products of Comamonas testosteroni Isolated from Estuarine Sediment
}

\author{
IMAN RUSMANA
}

\author{
Department of Biology, Institut Pertanian Bogor, Darmaga Campus, Bogor 16680, Indonesia \\ Phone/Fax: +62-251-622833, E-mail: rusmana13@yahoo.com
}

\begin{abstract}
Predictions of seasonal changes in $\mathrm{N}_{2} \mathrm{O}$ emission that occur in natural estuaries are important to anticipate the future implications of global warming. This study showed the effect of temperature on denitrifying growth and nitrate reduction end product of Comamonas testoteroni isolated from estuarine sediment using both batch and continuous cultures. The $\mu_{\max }$ values of Comamonas testosteroni grown in anaerobic batch culture were increased with increasing temperature, and the highest $\mu_{\max }$ was found at $26{ }^{\circ} \mathrm{C}$. Concentrations of nitrate reduced (mg-1 dried weight cells) were higher at low temperature. Concentrations of $\mathrm{N}_{2}$ produced were higher at low temperature and the production of $\mathrm{N}_{2}$ was higher than both $\mathrm{NO}_{2}^{-}$and $\mathrm{N}_{2} \mathrm{O}$ productions.
\end{abstract}

Key words: denitrification, nitrate reduction, nitrous oxide, Comamonas testosteroni

Denitrification and dissimilative nitrate reduction to ammonium are the major processes of nitrate removal in aquatic environments. Both processes have an implication for global warming, due to their emission of $\mathrm{N}_{2} \mathrm{O}$, a potential greenhouse gas. $\mathrm{N}_{2} \mathrm{O}$ concentration is currently increasing at $0.2-0.3 \%$ per year (Conrad 1995), and $90 \%$ of global $\mathrm{N}_{2} \mathrm{O}$ emission comes from biotic processes. Many studies have been conducted to determine whether denitrification or dissimilative nitrate reduction to ammonium is the process more responsible for nitrate removal and $\mathrm{N}_{2} \mathrm{O}$ production. In situ measurement of microbial activities can give valid information about undisturbed microbial activities in their natural condition, but this approach cannot describe the physiological process of microbial interaction due to the complexity of microbial communities. Microbial activities may also be studied under laboratory conditions, thereby allowing us to control experimental conditions. This laboratory experiment may help to get better understanding of the effect of temperature on denitrifying growth and end product of its nitrate reduction of Comamonas testoteroni isolated from estuary sediment. Characterization of denitrifying bacteria isolated from estuary sediment indicated that $C$. testosteroni has complete denitrification enzymes. It has $n a r \mathrm{G}, n a p \mathrm{~A}, \operatorname{nir} \mathrm{S}$, and nos $\mathrm{Z}$ genes. The end-product of nitrate/nitrite reduction in $20{ }^{\circ} \mathrm{C}$ was $100 \% \mathrm{~N}_{2}$ (Rusmana 2006).

Predictions of seasonal changes in dissimilative nitrate reduction process outcome that occur in natural environments are important to anticipate the future implications of global warming, this is especially so as denitrification can produce $\mathrm{N}_{2} \mathrm{O}$. Some in situ measurement studies suggested that denitrification was the dominant process at low temperature, whereas dissimilative nitrate reduction to ammonium at high temperature (King \& Nedwell 1984; Herbert \& Nedwell 1990; Ogilvie et al. 1997). In contrast, Zimmerman and Benner (1994) and Nowicki et al. (1997) showed the opposite results. Other experiments suggested that denitrification was the predominant process at low $\mathrm{C} / \mathrm{N}$ ratio, whereas DRNA predominated at high $\mathrm{C} / \mathrm{N}$ ratio environments (Koike \& Hatori 1978; Nedwell 1982). In additional Kandeler et al. (2006) sugested that nutrient availability may have contributed more to nitrate-reducing activities than to the density of the nitrate reducer community. Therefore this study was conducted to determine the effect of temperature on denitrifying growth and end product of its nitrate reduction of $C$. testoteroni isolated from estuary sediment.

\section{MATERIALS AND METHODS}

Effect of Temperature on End Products of Nitrate/Nitrite Reduction by $\boldsymbol{C}$. testosteroni in Batch Culture. The medium composition comprise as follow $\left(\mathrm{g} \mathrm{l}^{-1}\right): \mathrm{NaCl} 20.0, \mathrm{KCl} \mathrm{0.5}$, $\mathrm{Na}_{2} \mathrm{HPO}_{4} 5.5, \mathrm{NH}_{4} \mathrm{Cl} 0.5, \mathrm{~K}_{2} \mathrm{SO}_{4} 1.75, \mathrm{NaH}_{2} \mathrm{PO}_{4} 0.775, \mathrm{Na}_{2} \mathrm{EDTA}$ $0.078, \mathrm{MgSO}_{4} \cdot 7 \mathrm{H}_{2} \mathrm{O} 0.01, \mathrm{Na}$-acetate $0.68, \mathrm{KNO}_{3} 0.17$, Wolin's trace elements $(7 \mathrm{ml})$.

Sterile medium $(10 \mathrm{ml})$ was dispensed aseptically into sterile optically standardized tubes, triplicate for each temperature, capped with sterile suba-seals, and then gassed with OFN to make anaerobic by inserting a syringe needle through the suba-seal into the medium. An in-line sterile membrane filter $(0.2 \mu \mathrm{M}$ pore size, Sartorius $)$ was connected to the needle for sterilizing the OFN. To one of the three tubes was added $10 \%(\mathrm{v} / \mathrm{v}) \mathrm{C}_{2} \mathrm{H}_{2}$ to inhibit nitrous oxide reductase enzyme for determining total $\mathrm{N}_{2}$ end product. The tubes were placed in the holes across the temperature gradient block with triplicate tubes in each temperature. The temperature range was set between $6-32{ }^{\circ} \mathrm{C}$ with approximately $2{ }^{\circ} \mathrm{C}$ increments. After temperature equilibration, the tubes were inoculated with $200 \mu \mathrm{l}$ of exponential phase starter culture. Bacterial growth was monitored periodically using a nephelometer (EEL Unigalvo DS29, Diffusion Systems, London) to measure the OD in each tube. When the culture had reached stationary phase, $200 \mu \mathrm{l}$ of the headspace gas was injected into the GC to measure $\mathrm{N}_{2} \mathrm{O}$ gas. The culture was then centrifuged at 12,000 $\mathrm{xg}$ for $15 \mathrm{~min}$, and the supernatant was frozen and placed in 
the $-20^{\circ} \mathrm{C}$ freezer for further analyses of nitrate, nitrite, and ammonium.

The maximum specific growth rate $\left(\mu_{\max }\right)$ of the bacterium for each temperature was calculated by least square regression analysis of the slope of the linear part of semilogaritmic plot of turbidity versus time (Pirt 1975; Nedwell \& Rutter 1994).

End-Products of Nitrate Reduction by C. testosteroni in Steady State Chemostats. The continuous culture was conducted at four different temperatures, $5,10,15$, and $20^{\circ} \mathrm{C}$, using a chemostat that consisted of a glass vessel with a volume of $500 \mathrm{ml}$, sealed with a rubber bung. To minimize adherence of bacteria, "repelcote" (BDH) was used to coat the vessel glass wall. Sterile medium was pumped continuously using a peristaltic pump (multiperpex; LKB, Broma, Sweden) with dilution rate $0.02 \mathrm{~h}^{-1}$ for incubation at 10,15 , and $20{ }^{\circ} \mathrm{C}$, and $0.01 \mathrm{~h}^{-1}$ for incubation at $5^{\circ} \mathrm{C}$. A double line breaker connecting the reservoir vessel with the chemostat was used to prevent back contamination of sterile medium in the flow line. An aerobic condition was maintained by gassing the vessel and medium with sterile OFN. The OFN flow rate, $6 \mathrm{ml} \mathrm{min}$, was monitored by a calibrated flow meter (RSI type) and the OFN was passed through a chromous acid trap to remove out any $\mathrm{O}_{2}$ contained in trace amounts. A magnetic stirrer mixed the chemostat culture and the temperature in the chamber was maintained by circulating coolant through a glass jacket around the growth vessel that regulated by a thermo-circulator (Grant CFC25, Grant instruments, Cambridge Ltd.) attached to a FH15 flow heater (Grant instruments, Cambridge Ltd.).

To calculate the $\mu_{\max }$, the dilution rate was increased so that the cells were washed out from the vessel faster than bacterial growth. The OD was monitored using a spectrophotometer at $550 \mathrm{~nm}$. The slope of a plot of $\ln \mathrm{OD}_{550}$ versus time was calculated, then the $\mu_{\max }$ was also calculated using the following formula (Pirt 1975):

$$
\mu_{\text {max }}=\mathrm{D}_{\text {washout }} \text { - slope }
$$

where $\mathrm{D}_{\text {washout }}=$ the dilution rate during washout. The half saturation constant for nitrate $\left(\mathrm{K}_{\mathrm{NO} 3}{ }^{-}\right)$, was calculated using the following formula (Pirt 1975):

$$
\mathrm{K}_{\mathrm{NO}^{-}}=\mathrm{s}^{*}\left(\mu_{\max }-\mathrm{D}\right) / \mathrm{D}
$$

Where $\mathrm{s}^{*}=$ residual nitrate concentration at steady state, $\mathrm{D}$ $=$ dilution rate during steady state. The specific affinity $\left(\mathrm{a}_{\mathrm{A}}\right)$ for nitrate was calculated for each temperature of chemostat run using the following formula:

$$
\mathrm{a}_{\mathrm{A}-}=\left(\mu_{\max } / \mathrm{K}_{\mathrm{NO} 3}{ }^{-}\right)
$$

Nitrous Oxide Analysis in Acetylene Block Samples. The gas chromatograph was used to analyse $\mathrm{N}_{2} \mathrm{O}$ as describe in Trimmer et al. (1998), the presence of $\mathrm{C}_{2} \mathrm{H}_{2}$ in injected samples can damage the ECD of the gas chromatograph, and therefore it was necessary to separate $\mathrm{C}_{2} \mathrm{H}_{2}$ from $\mathrm{N}_{2} \mathrm{O}$ using an external pre-column. A stainless steel $(2 \mathrm{~m} \times 2 \mathrm{~mm}$ i.d.) packed with Paropak Q (80-100 mesh) was used at $25^{\circ} \mathrm{C}$, (Millipore Corporate, Milliford, U.K.), with OFN as a carrier gas $\left(80 \mathrm{ml} \mathrm{min}^{-1}\right)$. The retention time of $\mathrm{N}_{2} \mathrm{O}$ was shorter than $\mathrm{C}_{2} \mathrm{H}_{2}$, and therefore $\mathrm{N}_{2} \mathrm{O}$ could be collected using a liquid nitrogen cryo-trap $\left(-196^{\circ} \mathrm{C}, 200 \mu 1\right.$ stainless steel sample loop) before the $\mathrm{C}_{2} \mathrm{H}_{2}$ came off the pre-column. After $\mathrm{N}_{2} \mathrm{O}$ was eluted, the $\mathrm{C}_{2} \mathrm{H}_{2}$ was switched to waste and the pre-column brought on-line into the main GC column. The cryo-trap $\mathrm{N}_{2} \mathrm{O}$ was mobilized into the main GC column by immersing the pre-column loop in warm water (Trimmer et al. 1998).

\section{RESULTS}

Growth Kinetics of $\boldsymbol{C}$. testosteroni Batch Culture in Temperature Gradient Block. The $\mu_{\max }$ values of $C$. testosteroni batch culture in the temperature gradient block with acetate as a substrate is shown in Figure 1. The $\mu_{\mathrm{m}}$ values were increased with increasing the temperatures of incubation, and the highest $\mu_{\max }$ was found at $26^{\circ} \mathrm{C}$. The natural $\log$ of $\mu_{\max }$ plotted with the reciprocal of the absolute temperature shows that the plot was linear between $12{ }^{\circ} \mathrm{C}$ and $22^{\circ} \mathrm{C}(\mathrm{p}<0.001)$ (Figure 2). These results indicated that C. testosteroni is a mesophilic bacterium.

Concentrations of nitrate reduced $\mathrm{mg}^{-1}$ dried weight cells were higher at low temperature, $<10^{\circ} \mathrm{C}$. Similar with nitrate reduced, concentrations of $\mathrm{N}_{2}$ produced at temperature $<10^{\circ} \mathrm{C}$ (Figure 3) were higher at low temperature. $\mathrm{N}_{2}$ production from C. testosteroni was higher than both $\mathrm{NO}_{2}^{-}$and $\mathrm{N}_{2} \mathrm{O}$ productions. However, there was a peak of high nitrite concentration at $10^{\circ} \mathrm{C}$ compared with the other temperatures. $\mathrm{N}_{2} \mathrm{O}$ was only produced by $C$. testosteroni in small amount in all temperatures.

The percentages of nitrate reduced to $\mathrm{N}_{2}$ gas were higher than that reduced to $\mathrm{NO}_{2}{ }^{-}$and $\mathrm{N}_{2} \mathrm{O}$ gas, between 35.46 and $65.26 \%$, at 30 and $10{ }^{\circ} \mathrm{C}$ respectively (Figure $4 \&$ Table 1 ).

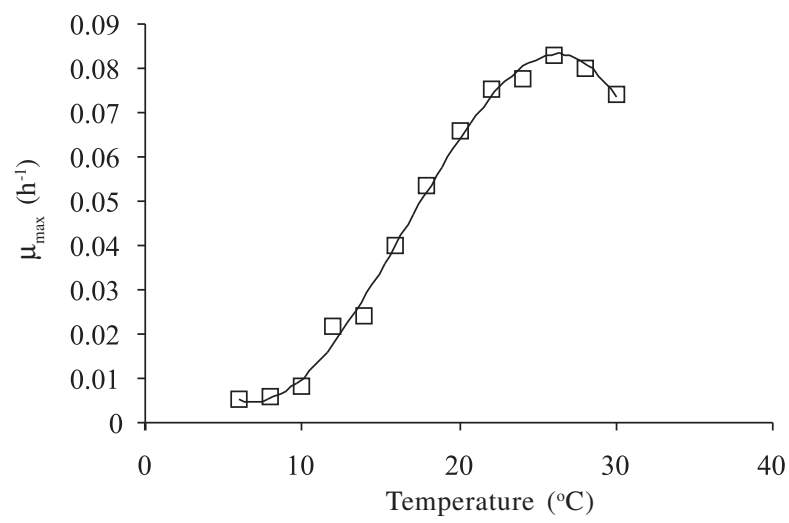

Figure 1 The maximum specific growth rate $\left(\mu_{\max }\right)$ values of Comamonas testosteroni batch cultures with acetate as a substrate in a temperature gradient block incubator.

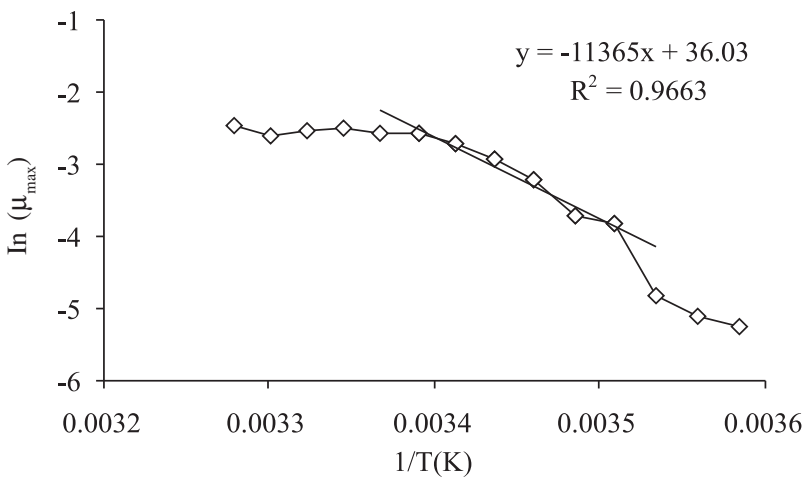

Figure 2 An Arrhenius semilogarithmic plot of the $\ln \mu_{\max }$ of Comamonas testosteroni versus the reciprocal of the absolute temperatures. A least square regression line was fitted to a linear section of the plot. 
Nitrate reduced to nitrite was between 0.15 and $8.69 \%$, at 28 and $10{ }^{\circ} \mathrm{C}$ respectively, and only between $0.78 \%$ (at $26{ }^{\circ} \mathrm{C}$ ) and $2.34 \%$ (at $8^{\circ} \mathrm{C}$ ) were reduced to $\mathrm{N}_{2} \mathrm{O}$. The total nitrate recovery was between 36.58 and $75.70 \%$, at 30 and $10{ }^{\circ} \mathrm{C}$ respectively (Table 1).

Growth Kinetics of $C$. testosteroni in Nitrate-Limited Continuous Culture with Acetate as a Substrate at 5, 10, $\mathbf{1 5}$, and $20{ }^{\circ} \mathbf{C}$. Cell density at steady state in anaerobic

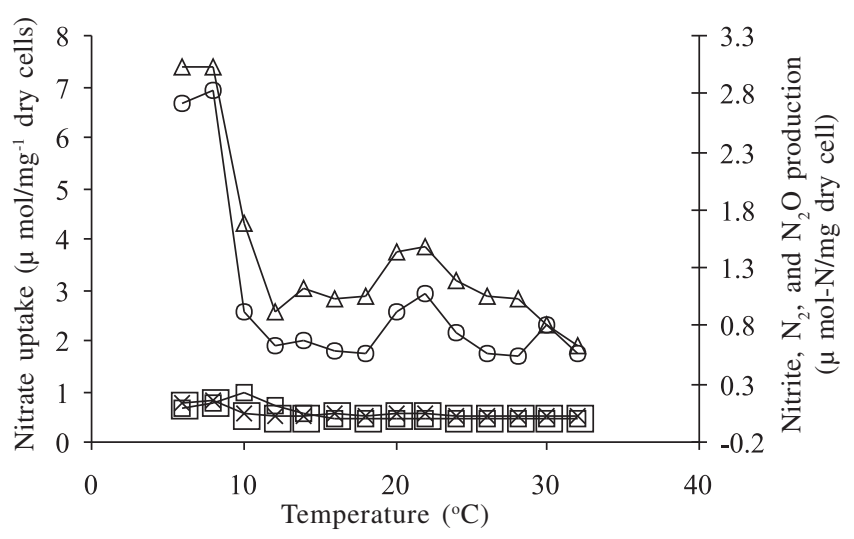

Figure 3 Temperature effect on nitrate (o ) uptake and nitrite, ( $\square$ ) dinitrogen $(\Delta)$, and nitrous oxide $(X)$ production per dried weight cells from Comamonas testosteroni batch cultures with acetate as a substrate.

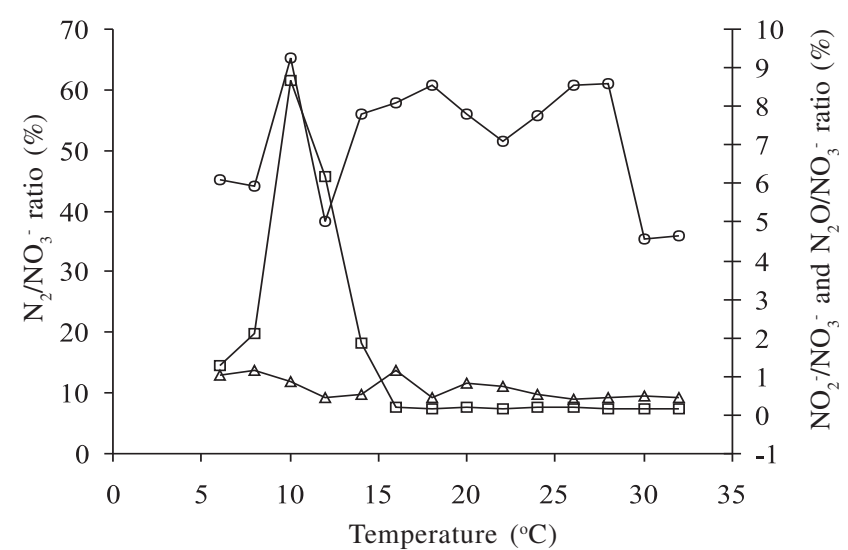

Figure 4 Percentage ratios of the nitrite ( $\mathrm{O}$ ), dinitrogen, ( $\square$ ) and nitrous oxide $(\Delta)$ production per nitrate removal basis from Comamonas testosteroni batch culture in a temperature gradient block incubator. continuous cultures with acetate as a substrate is shown in Figure 5. The ell density at steady state increased with increasing temperature, which were $1.58 \pm 0.12,2.70 \pm 0.57$, $7.77 \pm 1.04$, and $29.75 \pm 3.21 \times 10^{6} \mathrm{CFUs} \mathrm{ml}^{-1}$, at $5,10,15$, and $20{ }^{\circ} \mathrm{C}$ respectively. Total concentrations of nitrate reduced also increased with increasing temperature, which were 40.00 $\pm 8.02,253.94 \pm 69.54,816.96 \pm 39.88$, and $995.31 \pm 2.74 \mu \mathrm{M}$ at $5,10,15$, and $20^{\circ} \mathrm{C}$ (Figure 6). However, the highest amount of nitrate reduced per bacterial cell basis was at $15^{\circ} \mathrm{C}$, which

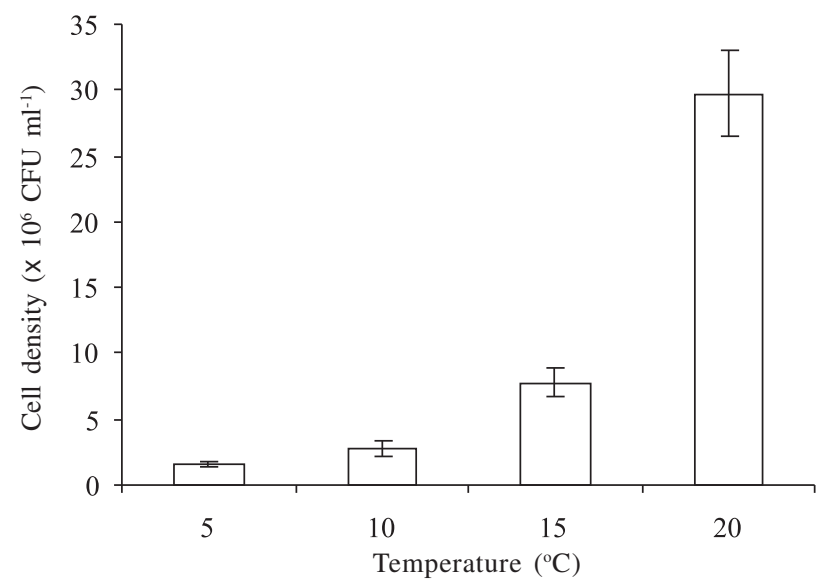

Figure 5 Cell density of Comamonas testosteroni continuous cultures in steady state at $5,10,15$, and $20{ }^{\circ} \mathrm{C}$. Bars indicate standard errors.

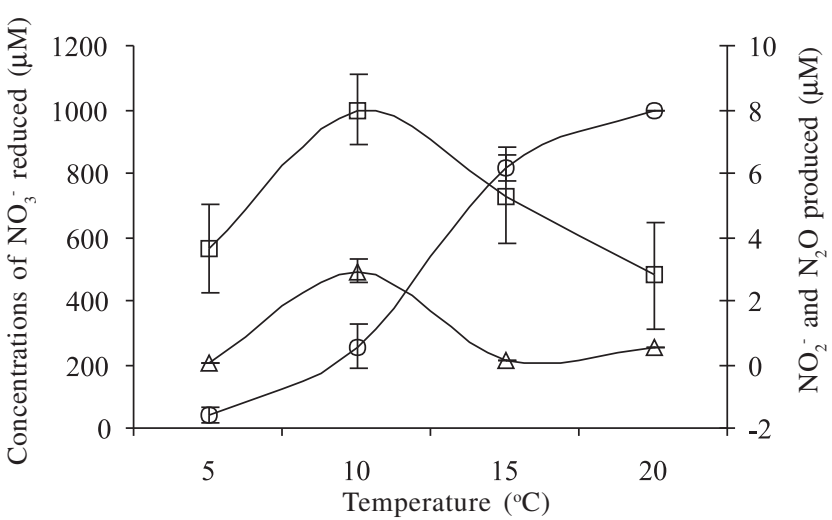

Figure 6 Concentrations of nitrate $(O)$ reduced, nitrite $(\square)$ and $\mathrm{N}_{2} \mathrm{O}(\Delta)$ produced in steady state condition of Comamonas testosteroni continuous culture at $5,10,15$, and $20^{\circ} \mathrm{C}$. Bars indicate standard errors.

Table 1 Cell dried weight, nitrate utilisation, and production of nitrite, dinitrogen, and nitrous oxide from C. testosteroni batch culture in temperature gradient block $( \pm$ standard error $)$

\begin{tabular}{|c|c|c|c|c|c|c|c|c|c|c|c|}
\hline \multirow{3}{*}{$\begin{array}{c}\text { Temperature } \\
\left({ }^{\circ} \mathrm{C}\right)\end{array}$} & \multirow{3}{*}{$\begin{array}{l}\text { Cell dried } \\
\text { weight } \\
(\mathrm{mg})\end{array}$} & \multicolumn{8}{|c|}{ Amounts of } & \multirow{3}{*}{$\begin{array}{l}\text { Cellular } \mathrm{N} \text { from } \\
\text { ammonium } \\
(\mu \mathrm{mol})\end{array}$} & \multirow{3}{*}{$\begin{array}{l}\mathrm{NO}_{3}^{-} \\
\text {recovery } \\
(\%)\end{array}$} \\
\hline & & \multicolumn{2}{|c|}{$\mathrm{NO}_{3}^{-}$reduced } & \multicolumn{2}{|c|}{$\mathrm{NO}_{2}^{-}$produced } & \multicolumn{2}{|c|}{$\mathrm{N}_{2}$ produced } & \multicolumn{2}{|c|}{$\mathrm{N}_{2} \mathrm{O}$ produced } & & \\
\hline & & $(\mu \mathrm{mol})$ & $(\%)$ & $(\mu \mathrm{mol})$ & $(\%)$ & $(\mu \mathrm{mol}-\mathrm{N})$ & $(\%)$ & $(\mu \mathrm{mol}-\mathrm{N})$ & $(\%)$ & & \\
\hline 32 & $17.33=$ & $.84 \pm 1.20$ & 93 & $05 \pm 0.002$ & 0.16 & 10.74 & 35.98 & $.28 \pm 0.036$ & 0.94 & $7.54 \pm 0$ & 37.09 \\
\hline 30 & $0 \pm$ & $89 \pm 3.47$ & & $5 \pm 0.001$ & 0.16 & 10.60 & & $28 \pm 0$ & 0. & $65 \pm 0.016$ & 36.58 \\
\hline 28 & $17.67 \pm 0.03$ & $.93 \pm 1.28$ & 7 & $04 \pm 0.004$ & 0.15 & 18.28 & 61 & $.26 \pm 0.018$ & 0.86 & $7.68 \pm 0.012$ & 62.09 \\
\hline 26 & $17.33 \pm 0.03$ & $29.97 \pm 0.90$ & 0 & $6 \pm 0.009$ & 0.19 & 18.20 & & $.24 \pm 0.001$ & 0.39 & $7.54 \pm 0.012$ & 61.69 \\
\hline 24 & $14.00 \pm 0$ & $29.97 \pm 2.12$ & 90 & $6 \pm 0.013$ & 0.19 & 16.74 & & $32 \pm 0$ & 1. & $6.09 \pm 0$ & 57.14 \\
\hline 22 & $10.33 \pm$ & $29.95 \pm 2.68$ & 83 & $5 \pm 0$ & 0.16 & 15.42 & 51 & $46 \pm$ & 1.52 & $4.49 \pm$ & 53.17 \\
\hline 20 & 11. & $29.96 \pm 1$ & 8 & $6 \pm$ & 0.18 & 16.75 & & $50 \pm$ & 1. & 08 & 57.88 \\
\hline 18 & 17 & $29.91 \pm$ & 9 & 01 & 0.18 & 18.18 & & 07 & 0.94 & & 61.91 \\
\hline 16 & 16 & $29.99 \pm 0.69$ & 99.96 & $0.06 \pm$ & 0.21 & 17.36 & & 13 & 2.28 & 16 & 60.38 \\
\hline 14 & $0 \pm$ & $30.00 \pm 0.00$ & 100.00 & $0.56 \pm c$ & 1.85 & 16.78 & & $0.32 \pm$ & 1. & & 57.87 \\
\hline 12 & $15.67 \pm 0.01$ & $30.00 \pm 0.00$ & 100.00 & $1.85 \pm 0.405$ & 6.18 & 14.28 & 48.28 & $0.28 \pm c$ & 0.92 & $6.82 \pm 0.004$ & 55.38 \\
\hline 10 & $7.67 \pm 0.001$ & $19.80 \pm 1.47$ & 66.00 & $1.72 \pm 0.131$ & 8.69 & 12.92 & 65.26 & $0.34 \pm 0.033$ & 1.76 & $3.34 \pm 0.002$ & 75.70 \\
\hline 8 & $2.67 \pm 0.001$ & $18.40 \pm 2.25$ & 61.33 & $0.39 \pm 0.134$ & 2.11 & 8.12 & 44.08 & $0.44 \pm 0.006$ & 2.34 & $1.16 \pm 0.002$ & 48.53 \\
\hline 6 & $2.33 \pm 0.01$ & $15.60 \pm 1.65$ & 52.00 & $0.20 \pm 0.014$ & 1.29 & 7.03 & 45.20 & $0.32 \pm 0.016$ & 2.06 & $1.01 \pm 0.004$ & 48.55 \\
\hline
\end{tabular}




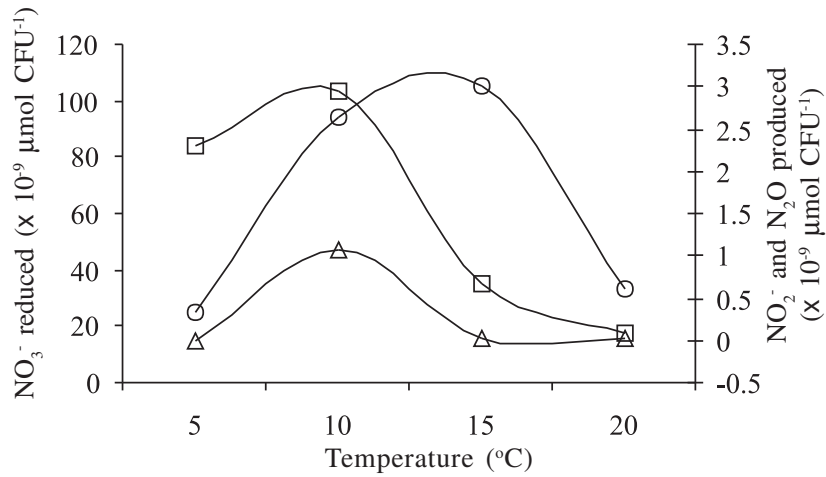

Figure 7 Amounts of nitrate ( $O$ ) reduced, nitrite ( $\square$ ) and $\mathrm{N}_{2} \mathrm{O}$ $(\Delta)$ produced per bacterial cell basis $\left(\mathrm{CFU}^{-1}\right)$ in steady state condition of Comamonas testosteroni continuous culture at 5, 10, 15, and 20 ${ }^{\circ} \mathrm{C}$.

Table 2 Kinetic growth rate parameters of C. testosteroni in nitrate-limited continuous culture experiments at 10,15 , and $20^{\circ} \mathrm{C}$

\begin{tabular}{cccrc}
\hline $\begin{array}{c}\text { Temperature } \\
\left({ }^{\circ} \mathrm{C}\right)\end{array}$ & $\begin{array}{c}\mu_{\max } \\
\left(\mathrm{h}^{-1}\right)\end{array}$ & $\begin{array}{c}\text { Residual nitrate } \\
\left(\mu \mathrm{mol} 1^{-1}\right)\end{array}$ & $\begin{array}{c}\mathrm{K}_{(\mathrm{no3}-)} \\
\left(\mu \mathrm{mol} \mathrm{1}^{-1}\right)\end{array}$ & $\begin{array}{c}\mathrm{a}_{\mathrm{A}(\mathrm{NO} 3-)} \\
\left(1 \mu \mathrm{mol}^{-1} \mathrm{~h}^{-1}\right)\end{array}$ \\
\hline 20 & 0.22176 & 104.69 & 1056.09 & 0.00021 \\
15 & 0.09276 & 283.03 & 1029.67 & 0.00009 \\
10 & 0.03276 & 846.05 & 539.78 & 0.00006 \\
\hline
\end{tabular}

was $105.18 \times 10^{-9} \mu \mathrm{mol} \mathrm{CFU}^{-1}$ (Figure 7). The highest concentrations of nitrite and $\mathrm{N}_{2} \mathrm{O}$ produced in both total and per bacterial cell basis were found at $10^{\circ} \mathrm{C}$, which were 77.99 $\pm 1.11 \mu \mathrm{M}$ or $2.96 \times 10^{-9} \mu \mathrm{mol} \mathrm{CFU}^{-1}$ and $2.92 \pm 0.34 \mu \mathrm{M}$ or 1.08 $\times 10^{-9} \mu \mathrm{mol} \mathrm{CFU}^{-1}$ respectively (Figure $5 \& 7$ ).

The kinetic growth rate parameters calculated using the formula reported by Pirt (1975) are shown in Table 2. The maximum specific growth rate $\left(\mu_{\max }\right)$ values at 10,15 , and $20^{\circ} \mathrm{C}$ were $0.03276,0.09276$, and $0.22176 \mathrm{~h}^{-1}$ respectively, and the specific affinity $\left(\mathrm{a}_{\mathrm{A}}\right)$ for nitrate at 10,15 , and $20^{\circ} \mathrm{C}$ were $0.00006,0.00009$, and $0.000211 \mu \mathrm{mol}^{-1} \mathrm{~h}^{-1}$ respectively (Table 3 ).

\section{DISCUSSION}

The $\mu_{\max }$ values of $C$. testosteroni grown in anaerobic batch culture with acetate as a substrate indicated that $C$. testosteroni is a mesophilic bacterium with optimum temperature for anaerobic growth at $26{ }^{\circ} \mathrm{C}$ (Figure 1). The Arrhenius plot of $\ln \mu_{\max }$ with $1 / \mathrm{T}^{\circ} \mathrm{A}$ shows that the linear/ normal range temperature was between 12 and $22^{\circ} \mathrm{C}$. In this linear range the microbial growth can be predicted by extrapolation of the Arrhenius relationship (Ingraham et al. 1983) as follow:

$$
\ln \mu=\left(-\Delta \mathrm{E}^{*} / \text { gas constant }\right)(1 / \mathrm{T})+\mathrm{constant}
$$

where, $\mu$ is microbial growth rate, $\Delta \mathrm{E}^{*}$ is the activation energy, and $\mathrm{T}$ is temperature in Kelvin.

The temperature characteristic value, which is the slope of the Arrhenius plot of $C$. testosteroni in acetate/nitrate, indicated that $C$. testosteroni has small response of growth to increasing temperature. There is a correlation of temperature characteristic with the energy activation as a following formula (Ingraham et al. 1983):

Temperature characteristic $=\left(-\Delta \mathrm{E}^{*} /\right.$ gas constant $)$ where $\Delta \mathrm{E}^{*}$ is the activation energy.
Table 3 The Specific affinity $\left(\mathrm{a}_{\mathrm{A}}\right)$ for nitrate by nitrate respiring bacteria in anerobic nitrate-limited chemostats

\begin{tabular}{|c|c|c|c|c|c|}
\hline \multirow{2}{*}{ Substrate } & \multirow{2}{*}{ Organism } & \multicolumn{4}{|c|}{$\mathrm{a}_{\mathrm{A}}\left(1 \mu \mathrm{mol}^{-1} \mathrm{~h}^{-1}\right)$ at a temperature $\left({ }^{\circ} \mathrm{C}\right)$} \\
\hline & & 5 & 10 & 15 & 20 \\
\hline \multirow[t]{4}{*}{ Glucose } & K. pneumoniae* & & 0.00118 & 0.00488 & 0.013 \\
\hline & Aeromonas sp.* & & 0.0033 & 0.0015 & 0.00006 \\
\hline & Klebsiella oxytoca* & & 0.00011 & & 0.00059 \\
\hline & Citrobacter sp.* & 0.00003 & & & 0.00004 \\
\hline \multirow{3}{*}{ Acetate } & Klebsiella oxytoca* & & 0.00014 & & 0.00021 \\
\hline & Citrobacter sp.* & 0.00012 & & & 0.00021 \\
\hline & C. testosteroni** & & 0.00006 & 0.00009 & 0.00021 \\
\hline
\end{tabular}

Total nitrate reduced at low temperature, in both batch and continuous cultures, was lower than at high temperature (Table 1) indicating temperature limitation on bacterial nitrate uptake. Low temperature inhibits active transport of substrate and nutrient by reducing the fluidity of the membrane, which then influences transporters molecules in the membrane, presumably because stiffening of the membrane by lowered temperature repress transport protein efficiency (Nedwell 1999). Moir and Wood (2001) suggested that there are two different mechanisms of nitrate transport; (i) nitrate/nitrite antiporter and (ii) nitrate/proton symporter. Protein transporter of nitrate transport is NarK (Zumft 1997; Moir \& Wood 2001; Sharma et al. 2006). Currently it is reported that there are two different forms of NarK, NarK1, and NarK2 (Moir \& Wood 2001; Sharma et al. 2006). In Paracoccus denitrificans NarK1 is a nitrate/proton symporter and NarK2 is nitrate/nitrite antiporter (Wood et al. 2002). Sharma et al. (2006) suggested that only the NarK2 protein is required as a nitrate/nitrite transporter by Pseudomonas aeruginosa under denitrifying conditions. In the present experiments, this NarK efficiency was probably repressed by low temperature with stiffing of the membrane, so that nitrate uptake was repressed. The bacterial growth is correlated with substrate and nutrient uptake. In nitrate-limiting medium, nitrate is a limiting factor that controls bacterial growth. Therefore, the bacterial growth yield at low temperature was lower than at high temperature (Table 1).

The ability of an organism to scavenge (via its transporters) a substrate is dependent upon its affinity for that substrate. If affinity is described by specific affinity $\left(a_{A}\right)$ the higher the value, the greater is this affinity for this substrate (Nedwell 1999). The specific affinity $\left(a_{A}\right)$ value for nitrate of $C$. testosteroni decreased with decreasing temperature below the growth optimum (Table 2). This trend of decreased affinity for nitrate probably indicates decreasing functional efficiency of NarK as temperature declines. Nedwell (1999) termed that any substrate taken up by some from of active transport will be less available as temperature decreases because microorganism ability to seize the substrate declines at low temperature as a result of "temperature-modulated substrate affinity".

The specific affinity $\left(\mathrm{a}_{\mathrm{A}}\right)$ value for nitrate of $C$. testosteroni with acetate as a substrate at $10{ }^{\circ} \mathrm{C}$ was lower than Klebsiella oxytoca with acetate and K. pneumoniae, Aeromonas sp., $K$. oxytoca with glucose, as well as at $15^{\circ} \mathrm{C}$ with $K$. pneumoniae and Aeromonas sp. with glucose, and at $20^{\circ} \mathrm{C}$ with $K$. pneumoniae and $K$. oxytoca with glucose as a substrate. However there was similar $\mathrm{a}_{\mathrm{A}}$ value with $K$. 
oxytoca and Citrobacter at $20^{\circ} \mathrm{C}$ with acetate as a substrate (Table 3). In steady state of nitrate limiting chemostats, the ability of a bacterial cell to seize nitrate from the environment might be controlled by the affinity of the transport protein (Nedwell 1999). This $a_{A}$ values reflect the ability of one organism to outcompete the others.

\section{ACKNOWLEDGEMENTS}

This work was supported by a studentship grant from the Quality for Undergraduate Education (QUE) Project, Department of Biology, Bogor Agricultural University, Indonesia to I.R. Thanks also due to D.B. Nedwell Department Biological Sciences, University of Essex, Cholchester, United Kingdom for his great support and advice.

\section{REFERENCES}

Conrad R. 1995. Soil microbial processes involved in production and consumption of atmospheric trace gases. In: Jones JG (ed). Advance in Microbial Ecology. Vol 14. New York: Plenum Pr. p 207-250.

Herbert RA, Nedwell DB. 1990. Role of environmental factors in regulating nitrate respiration in intertidal sediments. In: Revsbech NP, Sorensen J (ed). Denitrification in Soil and Sediment, FEMS Symposium. New York: Plenum Publ. p 77-99.

Ingraham JL, Maaloe O, Neidhardt FC. 1983. Growth of Bacterial Cell. Massachusetts: Sinauer Associates.

Kandeler E, Deiglmayr K, Tscherko D, Bru D, Philippot L. 2006 Abundance of narG, nirS, nirK, and nos Z genes of denitrifying bacteria during primary successions of a glacier foreland. Appl Environ Microbial 72:5957-5962.

King D, Nedwell DB. 1984. The influence of nitrate concentration upon the end-products of nitrate dissimilation by bacteria in anaerobic salt marsh sediment. FEMS Microbiol Ecol 31:23-28.

Koike I, Hatory A. 1978. Denitrification and ammonia formation in anaerobic coastal sediments. Appl Environ Microbiol 35:278282.
Moir JB, Wood NJ. 2001. Nitrate and nitrite transport in bacteria. Cell Mol Life Sci 58:215-224.

Nedwell DB. 1982. Exchange of nitrate, and the products of bacterial nitrate reduction, between seawater and sediment from a U.K. saltmarsh. Estuarine Coast Shelf Sci 14:557-566.

Nedwell DB. 1999. Effect of low temperature on microbial growth: lowered affinity fro substrates limits growth at low temperature. FEMS Microbiol Ecol 30:101-111.

Nedwell DB, Rutter M. 1994. Influence of temperature on growth rate and competition between two psychrotolerant antartic bacteria: low temperature diminished affinity for substrate uptake. Appl Environ Microbiol 60:1984-1992.

Nowicki BL, Requintina E, van Keuren D, Kelly JR. 1997. Nitrogen losses through sediment denitrification in Boxton Harbor and Massachusetts Bay. Estuaries 20:626-639.

Ogilvie BG, Rutter M, Nedwell DB. 1997. Selection by temperature of nitrate-reducing bacteria from estuarine sediments: species composition and competition for nitrate. FEMS Microbiol Ecol 23:11-22.

Pirt SJ. 1975. In Principle of microbe and cell cultivation. Blackwell: Oxford.

Rusmana I 2006. Gaseus end products of nitrate and nitrite reduction by denitrifying pseudomonads isolated from estuarine sediment. J Mikrobiol Indones 11:63-66.

Sharma V, Noriega CE, Rowe JJ. 2006 Involvement of NarK1 and NarK2 proteins in transport of nitrate and nitrite in the denitrifying bacterium Pseudomonas aeruginosa PAO. Appl Environ Microbiol 72:695-701.

Trimmer M, Nedwell DB, Sivyer DB, Malcolm SJ. 1998. Nitrogen fluxes through the lower estuary of the river Great Ouse, England: the role of the bottom sediments. Mar Ecol Prog Ser 163:109124.

Wood NJ, Alizadeh T, Richardson DJ, Ferguson SJ, Moir JWB. 2002. Two domains of a dual-function NarK protein are required for nitrate uptake, the first step of denitrification in Paracoccus pantotrophus. Mol Microbiol 44:157-170.

Zimmerman AR, Benner R. 1994. Denitrification, nutrient regeneration and carbon mineralisation in sediments of Gaverston Bay, Texas, USA. Mar Ecol Prog Ser 114:275-288.

Zumft W. 1997. Cell biology and molecular basis of denitrification. Microbiol Mol Biol Rev 61:533-616. 
